\title{
DIFFERENCES IN EXOENZYME PRODUCTION AND ADHERENCE ABILITY OF Candida spp. ISOLATES FROM CATHETER, BLOOD AND ORAL CAVITY
}

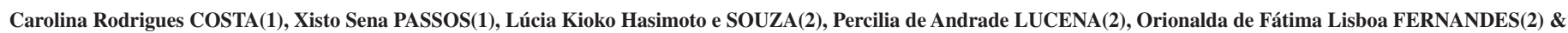
Maria do Rosário Rodrigues SILVA(2)

\begin{abstract}
SUMMARY
Phospholipase and proteinase production and the ability of adhesion to buccal epithelial cells (BEC) of 112 Candida isolates originated from oral cavity of HIV infected patients and from blood and catheter of intensive care unit patients were investigated. The proteinase production was detected by inoculation into bovine serum albumin (BSA) agar and the phospholipase activity was performed using egg yolk emulsion. A yeast suspension of each test strain was incubated with buccal epithelial cells and the number of adherence yeast to epithelial cells was counted. A percentage of $88.1 \%$ and $55.9 \%$ of Candida albicans and $69.8 \%$ and $37.7 \%$ of non-albicans Candida isolates produced proteinase and phospholipase, respectively. Non-albicans Candida isolated from catheter were more proteolytic than C. albicans isolates. Blood isolates were more proteolytic than catheter and oral cavity isolates while oral cavity isolates produced more phospholipase than those from blood and catheter. C. albicans isolates from oral cavity and from catheter were more adherent to BEC than non-albicans Candida isolates, but the adhesion was not different among the three sources analyzed. The results indicated differences in the production of phospholipase and proteinase and in the ability of adhesion to BEC among Candida spp. isolates from different sources. This study suggests that the pathogenicity of Candida can be correlated with the infected site.
\end{abstract}

KEYWORDS: Adherence ability; Candida; Exoenzyme activity.

\section{INTRODUCTION}

Many Candida species can be carried as an oral commensal by healthy individuals but they can cause opportunistic infection, especially in HIV patients, the elderly, neonates and patients undergoing chemotherapy, antibacterial therapy or invasive procedures ${ }^{22,24,27}$. HIV infected patients often develop oropharyngeal candidiasis, while candidemia has been cited as the fourth most frequent bloodstream infection in patients at intensive care units (ICUs) in the USA US, $13,28^{2}$

In addition to predisposing factors related to the host, Candida species are able to cause infection depending on intrinsic characteristics related to the microorganism itself. Germ tube production, growth at $37{ }^{\circ} \mathrm{C}$, protease and phospholipase production and adherence ability to BEC are considered important factors in establishing the infection ${ }^{14,16,29}$. Proteinase and phospholipase production can lead to dysfunction or even rupture of cellular membranes, which facilitate adhesion of the microorganism to the host $^{20,21}$. The successful colonization and infection by a microorganism depend upon their initial capacity to adhere to host tissue $e^{3,29}$.

In the present study, we investigated the in vitro phospholipase and proteinase activity and the ability of the adhesion to BEC of $C$. albicans and non-albicans Candida isolates from oral cavity of HIV infected patients and from blood and catheter of hospitalized patients in ICU.

\section{MATERIALS AND METHODS}

A total of 112 Candida strains isolated from three sources [58 obtained from oral cavity of HIV-infected patients and 54 obtained from patients in the intensive care unit (ICU) of a tertiary hospital (33 from catheter and 21 from blood)] were included in this study. The samples from oral cavity were obtained by swabbing the oral mucosa from Candida carriage patients undergoing antiretroviral therapy. The samples from the catheter were collected from the tip, and the last 3 to $5 \mathrm{~cm}$ of the catheter, and were cultured.

All the patients gave written informed consent and the study was approved by the Bioethics Committee of Hospital de Doenças Tropicais de Goiás (protocol 007/2004) and of Hospital das Clinicas da Universidade Federal de Goiás (protocol 027/07). Species stratification of the various isolates is as follows: 59 Candida albicans, 22 Candida parapsilosis, 14 Candida tropicalis, seven Candida guilliermondii, five Candida famata, three Candida krusei, one Candida lusitaniae, and one Candida kefyr. Candida strains were identified by germ tube test,

(1) Universidade Paulista, Goiânia, GO, Brasil.

(2) Instituto de Patologia Tropical e Saúde Pública, Universidade Federal de Goiás.

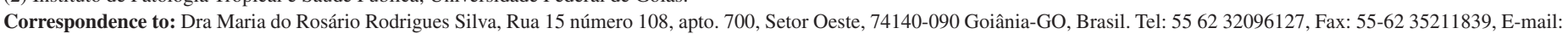
rosario@iptsp.ufg.br 


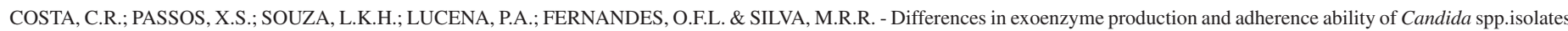
from catheter, blood and oral cavity. Rev. Inst. Med. Trop. Sao Paulo, 52(3):139-43, 2010.

clamidoconidia formation, carbon and nitrogen assimilation and sugar fermentation ${ }^{18}$. In addition, all the isolates were streaked in parallel onto CHROMagar ${ }^{\circledR}$ Candida medium plates (CHROMagar, Paris, France) for presumptive identification of $C$. albicans. API 20 Candida identification kit (bioMérieux, France) was used when the yeast could not be identified by the methods cited above. Growth at $45{ }^{\circ} \mathrm{C}$ on Sabouraud dextrose broth, and assimilation tests by using xylose and $\alpha$ methyl-D-glucoside were used to help us to discriminate between $C$. albicans and Candida dubliniensis ${ }^{7,8}$. All isolates were stored in sterile distilled water at room temperature and subsequently inoculated onto Sabouraud dextrose agar (SDA- DIFCO) for $24-48$ hours at $35^{\circ} \mathrm{C}$ for subsequent analysis. The assays were repeated three times for each isolate studied.

Detection of secreted aspartyl proteinase: The proteinase production was detected by the method of RUCHEL et al. ${ }^{25}$. Briefly, a single colony ( $\sim 6 \mathrm{~mm})$ from the Candida isolates was inoculated into bovine serum albumin (BSA) agar that contained yeast carbon base $(1.17 \%)$; protovit $(0.25 \%)$ and BSA $(0.2 \%)$, adjusted to $\mathrm{pH} 5.0$, sterilized by filtration, and added to autoclaved $2 \%$ agar. The plates were incubated at $37^{\circ} \mathrm{C}$ for five days. Proteolytic activity $(\mathrm{Pz})$ was measured by ratio of the diameter of colony and total diameter of colony plus precipitation zone as described by PRICE et al. ${ }^{23}$.

Detection of Phospholipase: The phospholipase production was assayed according to the method of PRICE et al. ${ }^{23}$. SDA medium supplemented with $1 \mathrm{~mol} / \mathrm{L}$ sodium chloride, $0.005 \mathrm{~mol} / \mathrm{L}$ calcium chloride and $8 \%$ sterile egg yolk emulsion (in natura) was poured $(20 \mathrm{~mL})$ in plates of $90 \mathrm{~mm}$ diameter and the single colony $(\sim 6 \mathrm{~mm})$ of each strain of the yeast was inoculated on the surface of the medium. The plates were incubated at $37{ }^{\circ} \mathrm{C}$ for five days. Phospholipase activity $(\mathrm{Pz})$ was measured according to proteinase testing.

Adhesion assay: This test was performed based on BIASOLI et $a l .{ }^{3}$. The buccal epithelial cells were obtained from the cheeks of healthy individuals. These cells were suspended in phosphate buffered saline (PBS - $\mathrm{pH} 7.2$ ), washed three times by centrifugation with the same buffer, and adjusted to a final concentration of $2 \times 10^{5}$ cells $/ \mathrm{mL}$. The yeast inoculum was prepared from cultures 24 h-old on Sabouraud dextrose agar. A colony originated from this growth was inoculated in Sabouraud glucose broth and incubated at $37{ }^{\circ} \mathrm{C}$ for $24 \mathrm{~h}$ with agitation. The yeasts were centrifuged, washed twice with PBS and the cell density was adjusted with a spectrophotometer (at $530 \mathrm{~nm}$ wavelength) to yield a yeast stock of $1 \mathrm{X} 10^{7}$ yeast $/ \mathrm{mL}$. Five hundred microliters of each yeast suspension was mixed with $500 \mu \mathrm{L}$ of the BEC pool and incubated at $37^{\circ} \mathrm{C}$ with agitation for one hour. The mixture was filtered through a $20 \mu \mathrm{m}$ size pore membrane filter. In order to remove non-adhered yeasts the filter was washed with 10 $\mathrm{mL}$ PBS and then transferred to a slide by pressing the filter paper against it. The cells fixed with methanol were stained using the Gram-Nicolle technique and the number of adhered cells to $100 \mathrm{BEC}$ was counted. The test was repeated three times and a mean value was defined.

Statistical analysis: The resulting data was statistically analyzed by SPSS for Windows version 11.0 using the mean and median of phospholipase, of proteinase and mean number $(\overline{\mathrm{x}})$ of yeast adhered to 100 BEC. The virulence differences of $C$. albicans and non albicans Candida isolates from blood, catheter and oral cavity were evaluated using Kruskal-Wallis. Mann Whitney test was used to verify the virulence differences between $C$. albicans and non albicans Candida isolates. A $p$-value of less than 0.05 was considered to be statistically significant.

\section{RESULTS}

Fifty two (88.1\%) C. albicans and 37 (69.8\%) non-albicans Candida isolates were proteinase positive $(p>0.05)$. Among the species of nonalbicans Candida, $C$. parapsilosis and $C$. guilliermondii showed a high proteinase activity $(81.8 \%$ and $85.7 \%$ respectively). The proteinase activity was observed in all isolates of $C$. famata (05) and of $C$. lusitaniae (01) obtained from catheter. Proteinase was produced by $41(70.6 \%)$ of the isolates from oral cavity, by $21(100 \%)$ of the isolates from blood and by $27(81.8 \%)$ of the isolates from catheter $(p=0.016)$. The comparison among Candida isolates from these sites showed that in catheter nonalbicans Candida were better proteinase producers than $C$. albicans isolates $(p<0.001)$ (Table 1).

Phospholipase production was detected in $33(55.9 \%)$ C. albicans isolates, and only in 20 (37.7\%) non-albicans Candida $(p>0.05) . C$.

Table 1

Number of Candida spp. isolates from oral cavity (58), blood (21) and catheter (33) positive for proteinase production

\begin{tabular}{|c|c|c|c|c|c|c|c|c|}
\hline \multirow[t]{2}{*}{ Species } & \multicolumn{2}{|c|}{ Oral cavity } & \multicolumn{2}{|c|}{ Blood } & \multicolumn{2}{|c|}{ Catheter } & \multicolumn{2}{|c|}{ Total } \\
\hline & $\mathrm{n} /$ total & $(\%)$ & $\mathrm{n} /$ total & $(\%)$ & $\mathrm{n} /$ total & $(\%)$ & $\mathrm{n} /$ total & $(\%)$ \\
\hline C. albicans & $29 / 31$ & 93.5 & $15 / 15$ & 100 & $08 / 13$ & 61.6 & $52 / 59$ & 88.1 \\
\hline non-albicans Candida & $12 / 27$ & 44.4 & $06 / 06$ & 100 & $19 / 20$ & 95.0 & $37 / 53$ & 69.8 \\
\hline C. parapsilosis & 05/09 & 55.6 & $03 / 03$ & 100 & $10 / 10$ & 100 & $18 / 22$ & 81.8 \\
\hline C. tropicalis & $04 / 13$ & 30.8 & $01 / 01$ & 100 & 0 & 0 & $05 / 14$ & 35.7 \\
\hline C. guilliermondii & $02 / 03$ & 66.7 & $02 / 02$ & 100 & $02 / 02$ & 100 & $06 / 07$ & 85.7 \\
\hline C. krusei & $01 / 01$ & 100 & 0 & 0 & $01 / 02$ & 50 & $02 / 03$ & 66.7 \\
\hline C. kefyr & $0 / 01$ & 0 & 0 & 0 & 0 & 0 & 0/01 & 0 \\
\hline C. lusitaniae & 0 & 0 & 0 & 0 & $01 / 01$ & 100 & 01/01 & 100 \\
\hline C. famata & 0 & 0 & 0 & 0 & $05 / 05$ & 100 & $05 / 05$ & 100 \\
\hline
\end{tabular}


kefyr and C. lusitaniae were phospholipase negative. Phospholipase was detected in $37(64 \%)$ of the isolates from oral cavity, in seven $(33.3 \%)$ from blood and in nine $(27.3 \%)$ from catheter. Oral cavity isolates were significantly higher producers of this enzyme than blood and catheter isolates $(p=0.003)$, but the comparison between species of Candida isolated from these sites did not show a significant difference (Table 2).

The adherence ability to BEC was higher in C. albicans $(\overline{\mathrm{x}}=227.5$ $\pm 107.1)$ than in non-albicans Candida $(\overline{\mathrm{x}}=154 \pm 76.5)(p<0.001)$. C. guilliermondii isolates showed a high adherence ability $(\overline{\mathrm{x}}=196.1$ \pm 93.7 ), but could not be statistically analyzed because the sample size was too small. The adhesion ability of Candida spp. from blood, catheter and oral cavity to BEC was similar $(p=0.113)$. The comparison among isolates and the sites showed that $C$. albicans isolates from oral cavity $(p=0.002)$ and from catheter $(p=0.032)$ were more adherent to BEC than non-albicans Candida isolates (Table 3 ).

The phenotypic tests used to discriminate between $C$. albicans and C. dubliniensis showed that this last species was not found in our study.

\section{DISCUSSION}

Phospholipase, proteinase activity and the adhesion of microorganisms to host cell surfaces are considered important virulence factors, facilitators of infection establishment, mainly in opportunist fungi ${ }^{4,29}$. There are several studies related to virulence factors of Candida species. According to some authors, secreted aspartic proteinases and phospholipase are produced at high rates in C. albicans, while non-albicans Candida species usually present low rates of these enzymes ${ }^{10,11,14,17}$. KOGA-ITO et al. ${ }^{16}$ showed an increased proteinase and phospholipase production among the $C$. albicans strains isolated from oral candidiasis patients when compared to those ones isolated from control individuals. There are few reports in the literature investigating the relationship of virulence in yeast species and sites in the host. In our work, proteinase and phospholipase were detected in $88.1 \%$ and $55.9 \%$ of C. albicans isolates and in $69.8 \%$ and $37.7 \%$ of non-albicans Candida, respectively. These results may be attributed to strain characteristics or be related to the site of infection. In blood isolates, independent of species, we found high proteinase activity; in oral cavity the production of this enzyme was higher in $C$. albicans than in non albicans, while the non-albicans Candida isolates

Table 2

Number of Candida spp. isolates from oral cavity (58), blood (21) and catheter (33) positive for phospholipase production

\begin{tabular}{lcccccccc}
\hline \multirow{2}{*}{ Species } & \multicolumn{2}{c}{ Oral cavity } & \multicolumn{2}{c}{ Blood } & \multicolumn{2}{c}{ Catheter } & \multicolumn{2}{c}{ Total } \\
\cline { 2 - 9 } & $\mathrm{n} /$ total & $(\%)$ & $\mathrm{n} /$ total & $(\%)$ & n/total & $(\%)$ & n/total & $(\%)$ \\
\hline C. albicans & $24 / 31$ & 77.4 & $07 / 15$ & 46.6 & $02 / 13$ & 15.4 & $33 / 59$ & 55.9 \\
non-albicans Candida & $13 / 27$ & 48.2 & $0 / 06$ & 0 & $07 / 20$ & 35.0 & $20 / 53$ & 37.7 \\
C. parapsilosis & $07 / 09$ & 77.8 & $0 / 03$ & 0 & $03 / 10$ & 30.0 & $10 / 22$ & 45.4 \\
C. tropicalis & $03 / 13$ & 23.1 & $0 / 01$ & 0 & 0 & 0 & $03 / 14$ & 21.4 \\
C.guilliermondii & $02 / 03$ & 66.6 & $0 / 02$ & 0 & $01 / 02$ & 50.0 & $03 / 07$ & 42.8 \\
C. krusei & $01 / 01$ & 100 & 0 & 0 & $01 / 02$ & 50.0 & $02 / 03$ & 66.7 \\
C. kefyr & $0 / 01$ & 0 & 0 & 0 & 0 & 0 & $0 / 01$ & 0 \\
C. lusitaniae & 0 & 0 & 0 & 0 & $0 / 01$ & 0 & $0 / 01$ & 0 \\
C. famata & 0 & 0 & 0 & 0 & $02 / 05$ & 40.0 & $02 / 05$ & 40.0 \\
\hline
\end{tabular}

Table 3

Results obtained for adherence testing according to the site of isolation

\begin{tabular}{|c|c|c|c|c|}
\hline \multirow[t]{2}{*}{ Etiology } & \multicolumn{4}{|c|}{ Average number of yeasts adhered $100 \mathrm{BEC}(\mathrm{SD})$} \\
\hline & $\begin{array}{c}\text { Oral cavity } \\
\overline{\mathrm{x}} \pm \text { SD }\end{array}$ & $\begin{array}{l}\text { Blood } \\
\overline{\mathrm{x}} \pm \text { SD }\end{array}$ & $\begin{array}{c}\text { Catheter } \\
\overline{\mathrm{x}} \pm \text { SD }\end{array}$ & $\begin{array}{c}\text { Total } \\
\overline{\mathrm{x}} \pm \text { SD }\end{array}$ \\
\hline C. albicans & $258.9 \pm 119.3$ & $180.7 \pm 51.5$ & $207.6 \pm 105.6$ & $227.5 \pm 107.1$ \\
\hline non-albicans Candida & $164.9 \pm 95.7$ & $130.8 \pm 46$ & $146.2 \pm 50.6$ & $154 \pm 76.5$ \\
\hline C. parapsilosis & $171.4 \pm 83.7$ & $126.0 \pm 46.9$ & $149.5 \pm 52.5$ & $155.3 \pm 65.6$ \\
\hline C. tropicalis & $125.2 \pm 87.6$ & $102^{\mathrm{a}}$ & - & $123.5 \pm 84.4$ \\
\hline C. guilliermondii & $258 \pm 109.2$ & $152.5 \pm 65.8$ & $147 \pm 66.5$ & $196.1 \pm 93.7$ \\
\hline Other species* & $254.5 \pm 54.5$ & - & $141.9 \pm 52.21$ & $164.4 \pm 68.6$ \\
\hline
\end{tabular}

a $=$ one isolate; $*$. kefyr, $C$. krusei, $C$. famata, $C$. lusitaniae - one isolate of each specie; $\overline{\mathrm{x}}=$ mean 
COSTA, C.R.; PASSOS, X.S.; SOUZA, L.K.H.; LUCENA, P.A.; FERNANDES, O.F.L. \& SILVA, M.R.R. - Differences in exoenzyme production and adherence ability of Candida spp.isolates from catheter, blood and oral cavity. Rev. Inst. Med. Trop. Sao Paulo, 52(3):139-43, 2010.

from catheter produced higher levels of proteinase. All the isolates of C. parapsilosis, C. guilliermondii, C. lusitaniae and C. famata were proteinase positive (no statistical analysis was made because of small sample sizes). High activity of this enzyme has been observed among isolates of C. parapsilosis in clinical specimens of hospitalized patients ${ }^{6}$.

On the other hand, although no significant differences of phospholipase production among the Candida isolates from different sources have been found, we verified that blood and catheter isolates presented lower phospholipase activity than oral cavity isolates (Table 2). PRICE et al. ${ }^{23}$ observed differences in the phospholipase activity in isolates from blood (55\%), wounds (50\%) and urine (30\%). The high phospholipase production in oral cavity found in our study is similar to some previous studies. One hundred percent phospholipase activity among oral mucosa isolates has been reported by KUMAR et al. ${ }^{17}$. Phospholipase production was also increased in the strains isolated from oral cavity of HIV infected patients according to KOGA-ITO et al. ${ }^{16}$.

Most of the studies have shown that $C$. albicans is more adherent to BEC than other Candida species $^{3,19}$. In our work, a significant difference $(p<0.001)$ was verified in adhesion of $C$. albicans and non-albicans Candida. C. albicans isolates from oral cavity and from catheter showed higher adhesion than non-albicans isolates. The high adhesion ability expressed by $C$. albicans may indicate more virulence when compared with non-albicans species. The adherence to host cell is considered an event probably connected to invasion of that cell or tissue ${ }^{26}$. Interestingly, high adhesion ability was verified among $C$. guilliermondii $(\overline{\mathrm{x}}=196.1 \pm 93.7)$ isolates. HENRIQUES et al. ${ }^{12}$ suggested that the factors which affect $C$ andida adhesion to epithelial cells can depend on the yeast. According to KENNEDY ${ }^{15}$, the adherence can be considered a specific multifactorial process involving several types of candida cell surface adhesins, as well as a variety of binding sites on host cells.

The non-identification of $C$. dubliniensis after the use of phenotypic tests validated by different researchers to distinguish them from $C$. albicans $^{1,2,9}$ shows that $C$. dubliniensis probably has a low incidence in our region.

In conclusion, the results of the present study indicated differences in phospholipase and proteinase activity which are closely related to Candida species and to sites where the samples were collected (catheter, blood and oral cavity). This work suggests that the pathogenicity of this yeast can be correlated with the infected site.

\section{RESUMO}

\section{Diferenças na produção de exoenzimas e habilidade de aderência entre isolados de espécies de Candida provenientes do cateter, sangue e cavidade bucal}

A produção de proteinase e fosfolipase e habilidade de adesão à célula epitelial bucal de 112 isolados de Candida originadas da cavidade bucal de pacientes infectados pelo HIV e de sangue e cateter de pacientes hospitalizados foram investigados. A produção de proteinase foi detectada por inoculação em ágar soro albumina bovina e a atividade de fosfolipase foi realizada usando emulsão de gema de ovo. A suspensão de levedura de cada isolado foi incubada com célula epitelial e o número de leveduras aderidas a célula epitelial foi contada. Uma porcentagem de 88,1 e 55,9\% de C. albicans e 69,8 e 37,7\% de isolados de Candida não albicans produziram proteinase e fosfolipase, respectivamente. Candida não albicans obtidas do cateter foram mais proteolíticos que isolados de Candida albicans ( $p<0,001$ ). Isolados do sangue foram mais proteolíticos do que isolados do cateter e cavidade bucal, enquanto isolados da cavidade bucal produziram mais fosfolipase do que aqueles isolados do sangue e cateter. C. albicans isoladas da cavidade bucal e do cateter foram mais aderentes à célula epitelial bucal do que isolados de Candida não albicans, mas não houve diferença na adesão entre os três locais analisados. Os resultados indicaram diferenças na produção de fosfolipase e proteinase e na habilidade de adesão à célula epitelial bucal entre os isolados de Candida das diferentes fontes. Este estudo sugere que a patogenicidade de Candida spp pode estar correlacionada ao local infectado.

\section{ACKNOWLEDGEMENTS}

The authors wish to acknowledge the financial support from "Conselho Nacional de Desenvolvimento Científico e Tecnológico (CNPq)”. Process - 474837/2006-8.

\section{REFERENCES}

1. Akgül O, Çerikçioglu N. Hypertonic Sabouraud dextrose agar as a substrate for differentiation of Candida dubliniensis. Mycopathologia. 2009;167:357-9.

2. Alves SH, Milan EP, Sant'Ana PL, Oliveira LO, Santurio JM, Colombo AL. Hypertonic Sabouraud broth as a simple and powerful test for Candida dubliniensis screening. Diagn Microbiol Infect Dis. 2002;43:85-6.

3. Biasoli MS, Tosello ME, Magaró HM. Adherence of Candida strains isolated from the human gastrointestinal tract. Mycoses. 2002;45:465-9.

4. Calderone RA, Fonzi WA. Virulence factors of Candida albicans. Trends Microbiol. 2001;9:327-35.

5. Cavassani VGS, Andrade Sobrinho JA, Homem MGN, Rapoport A. Candidíase oral como marcador de prognóstico em pacientes portadores do HIV. Rev Bras Otorrinolaringol. 2002;68:630-4.

6. Dagdeviren M, Cerikcioglu N, Karavus M. Acid proteinase, phospholipase and adherence properties of Candida parapsilosis strains isolated from clinical specimens of hospitalized patients. Mycoses. 2005;48:321-6.

7. Dolapci I, Tekeli A, Gocmen JS, Aysev D, Guriz H. Investigation of Candida dubliniensis in Candida spp.-positive hemocultures. APMS. 2002;110:391-5.

8. Faggi E, Pini G, Campisi E, Martinelli C, Difonzo E. Detection of Candida dubliniensis in oropharyngeal samples from human immunodeficiency virus infected and non-infected patients and in a yeast culture collection. Mycoses. 2005;48:211-5.

9. Fotedar R, Al-Hedaithy SSA. C. dubliniensis at a university hospital in Saudi Arabia. J Clin Microbiol. 2003;41:1907-11.

10. Fotedar R, Al-Hedaithy SSA. Comparison of phospholipase and proteinase activity in Candida albicans and C. dubliniensis. Mycoses. 2005;48:62-7.

11. Gokce G, Cerikcioglu N, Yagci A. Acid proteinase, phospholipase, and biofilm production of Candida species isolated from blood cultures. Mycopathologia. 2007; 164:265-9.

12. Henriques M, Azeredo J, Oliveira R. The involvement of physico-chemical interactions in the adhesion of Candida albicans and Candida dubliniensis to epithelial cells. Mycoses. 2007;50:391-6. 



from catheter, blood and oral cavity. Rev. Inst. Med. Trop. Sao Paulo, 52(3):139-43, 2010.

13. Jarvis WR. Epidemiology of nosocomial fungal infections, with emphasis on Candida species. Clin Infect Dis. 1995;20:1526-30.

14. Kantarcioglu AS, Yücel A. Phospholipase and protease activities in clinical Candida isolates with reference to the sources of strains. Mycoses. 2002;45:160-5.

15. Kennedy MJ. Adhesion and association mechanisms of Candida albicans. Curr Top Med Mycol. 1988;2:73-169.

16. Koga-Ito CY, Lyon JP, Vidotto V, Resende MA. Virulence factors and antifungal susceptibility of Candida albicans isolates from oral candidosis patients and control individuals. Mycopathologia. 2006;161:219-23.

17. Kumar CPG, Kumar SSJ, Menon T. Phospholipase and proteinase activities of clinical isolates of Candida from immunocompromised patients. Mycopathologia. 2006;161: 213-8.

18. Kurtzman CP, Fell JW, editors. The Yeast: a taxonomic study. $4^{\text {th }}$ ed. Amsterdam: Elsevier; 1998.

19. Lyon JP, Resende MA. Evaluation of adhesion to buccal epithelial cells in Candida species obtained from denture wearers after exposure to fluconazole. Mycoses. 2007;50:21-4.

20. Naglik JR, Challacombe SJ, Hube B. Candida albicans secreted aspartyl proteinases in virulence and pathogenesis. Microbiol Mol Biol Rev. 2003;67:400-28.

21. Niewerth M, Korting HC. Phospholipases of Candida albicans. Mycoses. 2001;44:361-7.
22. Pongsiriwet S, Iamaroon A, Sriburee P, Pattanaporn K, Krisanaprakornkit S. Oral colonization of Candida species in perinatally HIV-infected children in northern Thailand. J Oral Sci. 2004;46:101-5.

23. Price MF, Wilkinson ID, Gentry LO. Plate method for detection of phospholipase activity in Candida albicans. Sabouraudia. 1982;20:7-14

24. Resende JCP, Resende MA, Saliba JL. Prevalence of Candida spp. in hospitalized patients and their risk factors. Mycoses. 2002;45:306-12.

25. Ruchel R, Tegeler R, Trost M. A comparison of secretory proteinase from different strains of Candida albicans. Sabouraudia. 1982;20:233-44.

26. Sturtevant J, Calderone R. Candida albicans adhesins: biochemical aspects and virulence. Rev Iberoamer Micol. 1997;14:90-7.

27. Urizar JMA. Candidiasis orales. Rev Iberoam Micol. 2002;19:17-21.

28. Wisplinghoff H, Bischoff T, Tallent SM, Seifert H, Wenzel RP, Edmond MB Nosocomial bloodstream infections in US hospitals: analysis of 24,179 cases from a prospective nationwide surveillance study. Clin Infect Dis. 2004;39:309-17.

29. Yang YL. Virulence factors of Candida species. J Microbiol Immunol Infect 2003;36:223-8.

Received: 3 July 2009

Accepted: 3 March 2010 